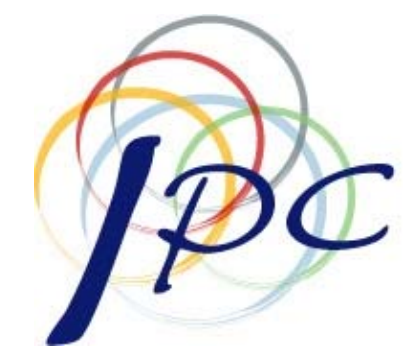

International Policy Center

Gerald R. Ford School of Public Policy University of Michigan

IPC Working Paper Series Number 13

\title{
Concepts of Fairness in the Global Trading System
}

Andrew G. Brown

Robert M. Stern

February 2006 


\title{
Concepts of Fairness in the Global Trading System
}

\author{
Andrew G. Brown \\ Wellfleet, $M A$ \\ Robert M. Stern \\ University of Michigan \\ IPC Working Paper No. 13 \\ February 2006
}

\author{
The International Policy Center \\ 735 S. State Street \\ Ann Arbor, MI 48109-3091 \\ USA \\ Phone: +1 7347632599 \\ Fax: +1 7347639181 \\ Email: fssp-IPC@umich.edu
}

Any opinions expressed here are those of the author(s) and not those of the Center. Research disseminated by IPC may include views on policy, but the Center itself takes no institutional policy positions.

The International Policy Center is based at the Gerald R. Ford School of Public Policy, University of Michigan. The IPC serves as an intellectual focal point for international research and education by bringing together academics at the University of Michigan to produce innovative research on key issues related to government, non- governmental organizations (NGOs) and business policies in the increasingly global world. Our broad areas of research interest include: international trade and finance; international political economy; comparative economic development; and global health issues. The IPC strives to generate rigorous policy-oriented research that advances the learning and research of Michigan faculty and students, as well as inform policy makers in international multilateral institutions.

IPC Working Papers often represent preliminary work and are circulated to encourage discussion. Citation of such a paper should account for its provisional character. A revised version may be available directly from the author. 


\title{
Concepts of Fairness in the Global Trading System
}

\section{Andrew G. Brown, Wellfleet, MA and Robert M. Stern, University of Michigan}

\begin{abstract}
How are we to assess the fairness of the global trading system as embodied in the GATT/WTO? Opinions about what constitutes fairness differ widely, and there is surely no incontrovertible yardstick. But can we be clearer about the criteria that are appropriate and what they mean in more operational terms?

In this paper, we first discuss why fairness is a condition of the agreements among governments that form the global trading system. We then suggest that fairness can best be considered within the framework of two concepts: equality of opportunity and distributive equity. We observe that the efficiency criterion is not a primary yardstick of fairness, and though it is relevant in choosing among alternative ways of realizing fairness, it is not without its own limitations. We thereafter discuss what equality of opportunity and distributive equity mean when applied to the commitments that governments make in the global trading system. For this purpose, we divide these commitments into four categories: those relating directly to market access; those concerning supporting rules designed to prevent cheating in market access commitments or to facilitate trade flows; those relating to procedures for the settlement of disputes or the use of trade remedy measures; and those relating to governance of the system. (We say nothing in this paper about the issue of fairness in the context of the last category.) Finally, we make some comments about fairness in the Doha Development Round, first reviewing some proposals made by Stiglitz and Charlton, and then making some observations about the central issue of market access.
\end{abstract}

Keywords: Fairness, Equality of Opportunity, Distributive Equity, Global Trading System

JEL Classification: D63, F02, F10, F13

February 5, 2006 (Revised)

Address correspondence to:

Andrew G. Brown

P.O. Box 1763

Wellfleet MA 02667

Ann Arbor MI 48109-1220

Tel: $\quad$ 508-349-0186

E-mail: abrown@c4.net
Robert M. Stern

Department of Economics

University of Michigan

Tel: $\quad$ 734-764-2373

E-mail: rmstern@umich.edu 


\section{Concepts of Fairness in the Global Trading System*}

\section{Andrew G. Brown, Wellfleet MA and Robert M. Stern, University of Michigan}

\section{Introduction}

How are we to assess the fairness of the global trading system as embodied in the GATT/WTO? Views about what constitutes fairness differ widely, and there is surely no incontrovertible yardstick. But can we be clearer about the criteria that are appropriate and what they mean in more operational terms?

Some would say that fairness is hardly a relevant idea in trade relations. There are the antiglobalization advocates who view the trading system as being dominated by powerful governments and corporations whose main concern is to enhance national interests and corporate profits to the possible detriment of the less fortunate within their own societies or the societies of poorer nations; they find capitalism to be inherently unfair. There are others who, though accepting the capitalist system, take a realpolitik view of trade relations. They share a view long ago expressed by Thucydides (1934) in connection with the Pelopennesian Wars (431-404 B.C.) in describing how the much weaker Melians were called upon by the powerful Athenians to surrender their city. The councilors of Melos appealed for fair treatment, but the Athenian ambassadors replied that "...right, as the world goes, is only a question between equals in power, while the strong do what they can and the weak suffer what they must."

We do not accept either of these views. We take capitalism as the institutional basis of the trading system, and we do not find the realpolitik view to be an accurate portrayal of modern trade relations. The developed countries that - until recently - dominated GATT/WTO negotiations have observed "right" by claiming to adhere, in principle, to reciprocity, Most-Favored-Nation (MFN) treatment, and national treatment in their trade relations. Though there have been some large differences in political and economic power, the stronger nations have not behaved in the manner portrayed by Thucydides; for, trade

\footnotetext{
* We wish to thank Dan Ciuriak, John Curtis, Alan Deardorff, Kimberly Elliott, Patrick Low, members of the University of Michigan Research Seminar in International Economics, and conference discussants and participants for helpful comments on earlier versions of the paper. We wish also to thank Judith Jackson for typing and editorial assistance.
} 
relations among modern nation states have not been based on military conquest but rely on cooperation secured through diplomatic persuasion.

The system of cooperation works within a skeletal framework of norms. The framework, however, leaves ample room for differences of views about fairness relating to such matters as the market access arrangements of trading partners, or their commercial practices, or even their different social standards as these affect trade. It is fairness in this context of inter-governmental trade relations, now greatly expanded to include numerous developing countries, that we address here.

We should note that our focus means that we do not directly address one other aspect of fairness relating to trade policies, namely, the internal distributional effects of these policies. It is certainly an important matter for domestic public policy that trade negotiations give rise to winners and losers within national economies. In this paper, we assume that these distributional issues will influence the negotiating stances of governments and affect their perceptions of fairness. In this way, they are part of our discussion of fairness in inter-governmental trade relations.

We take as a premise that, since membership in a system of cooperation like the GATT/WTO is voluntary, its rules and procedures rest on mutual consent. In the context of discussing fairness, this is a crucial characteristic. That is, unless there is a consensus about the fairness of the rules and procedures in the trading system, countries will not willingly abide by them indefinitely. Fairness is therefore an element in the existence and functioning of the system.

Such a system of cooperation is, to be sure, only approximated in reality. The powerful are more able to press for the adoption of rules and procedures that suit them, while the weak are more often obliged to compromise. It can be argued that, since participation is voluntary, no country need accept the negotiated outcomes if it believes that these run counter to its interests. But that is not necessarily so, since rejection would entail withdrawal from membership in the GATT/WTO altogether. A country would then lose all the rights embodied in the GATT/WTO regime, such as MFN treatment and the protections afforded by the dispute-settlement mechanism. Thus, there may be circumstances in which a country may emerge worse off from a round of negotiations, yet to find it has no choice but to accept the 
worsened status. Nevertheless, it remains true that, if ideas of fairness are seriously and persistently violated, the cooperation on which the system rests will be threatened and the system thereby undermined.

We do not explore the microfoundations of fairness, something that is addressed in the experimental and game- and negotiation-theory literature. ${ }^{1}$ We believe that, while the judgments of individuals or nations in matters affecting them have inescapably a self-serving bias, they can all recognize that fairness appears to be met when certain conditions are satisfied — like reciprocity in bargaining situations or equality of treatment in the application of common rules. ${ }^{2}$

In what follows, we argue that fairness in the global trading system can best be assessed in terms of two criteria: equality of opportunity and distributive equity. It should be understood that we do not advance equality of opportunity as a high moral principle. It is an instrumental criterion to be valued for its consequences, namely that it facilitates the reaching of inter-governmental agreements that protect and enhance the mutually advantageous trading system. Distributive equity can also be argued — somewhat more tendentiously — to be an instrumental criterion. That is, in correcting for the disadvantageous initial conditions faced by poorer countries, it is ensuring that all can respond to a legal, or formal, notion of equality of opportunity. For many of us, however, there is also a deontological element in the criterion insofar as we accept it as a moral obligation and do not insist upon it because of its advantages to

\footnotetext{
${ }^{1}$ See for example Carraro et al. (2005) for a review and synthesis of bargaining theory, negotiation, theory, and the theory of fair division.

${ }^{2}$ In an interesting and insightful paper, Suranovic (2000) has classified these conditions into seven principles divided between "equality fairness" and "reciprocity fairness". Equality fairness includes non-discrimination fairness, distributional fairness, and golden rule fairness. Reciprocity fairness includes positive reciprocity fairness, negative reciprocity fairness, privacy fairness, and maximum benefit fairness. Suranovic describes each of these conditions in detail and provides examples in the context of international trade. Narlikar (2005) interprets fairness to mean legitimacy of process and equity of outcomes in the context of the GATT/WTO. She traces the shifts in attitudes of developing countries towards the GATT/WTO in terms of how the balance between these two concepts has changed. Her idea of fairness as a composite resembles our framework, but there remain difficulties of integrating them. Risse (2005) analyzes considerations of fairness that stem from the trading relationships among countries that reflect differences in comparative advantage, levels of income, and social institutions.
} 
ourselves. The problem that confronts us in this paper thus lies in defining these criteria in more concrete and operational terms. ${ }^{3}$

It should be noted that we do not include the economists' yardstick of efficiency as a criterion of fairness. Efficiency is pertinent to the extent to which global resources are being used optimally. But no nation is likely to subscribe willingly to successive trade agreements that leaves it worse off, no matter the gain in global welfare. The efficiency yardstick is, however, important in choosing among alternative ways of fulfilling the conditions of fairness. And the analysis of alternatives may in itself alter the perception of fairness that influences agreements. We should nevertheless be aware that the yardstick of efficiency pervades much of the commentary on the global trading system, and — ambiguous though it also is - may tend to overshadow considerations of fairness.

For the purpose of our discussion, we classify the agreements of the global trading system into four categories: commitments dealing directly with market access, such as tariff schedules and service agreements; rules that support market-access commitments by preventing the use of other domestic measures that nullify or impair the commitments or by facilitating the flow of trade; rules dealing with the use of measures to defend against alleged "unfair” trade or with dispute-settlement procedures; and rules dealing with the governance of the system. We define and illustrate the application of our criteria to the first three categories. We say nothing in this paper on the last category though it also raises large issues of fairness.

In Section 2 following, we review the yardstick of efficiency in order to put it into perspective in the context of a discussion of fairness. In Section 3, we discuss equality of opportunity in market access. In Section 4, we ask what distributive equity means in relation to market access. In Section 5, we turn to equality of opportunity in regard to supporting rules. In Section 6, we briefly discuss procedural justice, which is a special case of equality of opportunity. In section 7, we consider fairness in the context of the

\footnotetext{
${ }^{3}$ Kapstein (2006) presents an analysis of fairness that is very similar to ours. Using a "liberal internationalist" model of international economic justice that focuses on nation states and their interactions, he interprets the multilateral trading system as being based on "diffuse reciprocity," which appears to be an amalgam of our fairness criteria of equality of opportunity and distributive equity.
} 
Doha Round, commenting briefly on the views of Stiglitz and Charlton $(2004,2005)$ and presenting views of our own, particularly on market access arrangements between developed and developing countries. Section 8 concludes.

\section{The Efficiency Criterion}

For political leaders and their trade diplomats, bargaining to win gains in market access has been at the core of trade negotiations, and this is what ideas of fairness have turned around. For economists, however, this has not conformed with their way of thinking about rational behavior. Defining rationality as the maximization of utility, they find gains in market access an unsatisfactory standard in that it fails to capture fully the welfare benefits arising from trade negotiations. That is, it focuses largely on the liberalization of export markets and not on the effects of trade liberalization as a whole. ${ }^{4}$

For many economists — borrowing from welfare theory — a practically acceptable criterion of fairness would be that the trade negotiations result in a more efficient global economy. Greater efficiency is defined as a movement toward Pareto optimality, and in the context of international trade, that state would be reached when no country can be made better off without some other being made worse off. If, however, the losing countries can be compensated by the gaining countries, still leaving the latter with some net benefit, this would qualify as an improvement in efficiency. This compensation rule is an important qualification in international trade since gains in allocative efficiency made by individual countries may be offset by losses arising from terms-of-trade effects. However, beyond this compensation rule, the efficiency criterion does not concern itself with the distribution among countries of the welfare benefit that accrues from the trade negotiations. It is a utilitarian view of fairness which says that, so long as no country gains at the expense of any other, no country has rational grounds for resisting multilateral trade liberalization.

\footnotetext{
${ }^{4}$ Wonnacott and Wonnacott (2005) have argued that economists have tended to fall into the opposite error of focusing too much on the gains from unilateral import liberalization, neglecting the gains that come from the reduction of foreign trade barriers through reciprocal tariff negotiations. This is misleading since, as they demonstrate, reciprocal tariff negotiations are economically superior to unilateral tariff reductions. The former provides added benefits that the latter cannot. Moreover, while both yield favorable efficiency gains, potentially
} 
For most non-economists (as well as for some economists), a criterion that does not address the distributional issue, appears quite strange; it seems to be evading a central aspect of fairness (a facet that is discussed below). Within the logic of general equilibrium analysis, however, the issue seems less relevant. Since the reasoning is that efficiency gains result from trade liberalization, the gains accruing to each country are determined, at least in part, by the country's own action in liberalizing its import trade. If it is within a country's own power to enhance its benefit from trade, the question of fairness among countries does not arise. It is true, however, that each country is affected by the others in so far as failure by the others to liberalize deprives it of the benefit of the expansion of its export industries. Thus, the one concern that the criterion has with the distribution of gains turns on the relative gains that countries make in gaining greater access to export markets.

Though many economists might generally admit that the criterion does not address the issue of the distribution of benefits among countries, they would still defend its value. They would argue that, in defining the conditions under which optimal output can be realized, it makes a major contribution to the assessment of policy measures affecting the functioning of markets. Its central theorem is that, provided certain restrictive assumptions are met, Pareto optimality would be realized when a state of equilibrium is reached in a perfectly competitive market; and so any movement toward this state constitutes a gain. Thus, most economists unhesitatingly support reductions in trade barriers as positive in their effects. They might admit that, because of the political economy of trade relations, the application of such a yardstick of efficiency to the outcome of multilateral trade negotiations may not be a sufficient answer to the question of fairness. But it does seem entirely reasonable that some assessment of the effects of the negotiations on the performance of markets is a relevant part of the overall judgment.

Disregard of the distributional issue is not the only criticism that can be leveled against this efficiency criterion. It derives from a theoretical model of the market economy that abstracts from many aspects of reality. Even when accepted on its own limited terms, it has to be qualified by recognition that market failures take place. In the context of international trade, it has long been accepted, for instance, 
that protection of infant industries on grounds of externalities is, at least in principle, a legitimate exception. Further, still within its own terms of static equilibrium analysis, the criterion disregards the costs of adjustment to a new state of equilibrium that follow from trade liberalization. These can be of no small importance. It is one characteristic of many economies - especially of those in the process of development — that they suffer from major structural rigidities arising from poorly functioning markets and institutional deficiencies. Adjustments to changes in market conditions can take many years. This is especially true of agriculture. Thus, for example, in response to lower-cost imports of foreign food, peasant farmers growing staple crops for subsistence and sale may be forced to abandon their land and join the ranks of the underemployed in the cities. Reemployment of the land may have to wait years for sufficient improvements in the rural infrastructure and institutions — such as the marketing arrangements, transport, farm-extension services, or the reform of land ownership — before more productive, and competitive, farming can reemerge. In poor economies with large pools of labor, both land and labor may thus remain idle for many years. Potential output may be lost and, what is perhaps worse, the erosion in the structure of rural society may endanger social cohesion.

The criterion of efficiency is also vulnerable to major criticism because it derives from static equilibrium analysis. It defines efficiency in terms of optimal resource allocation and not in terms of the long-term rate of growth in output. If efficiency is redefined to include the long term increase in output resulting from productivity growth and resource accumulation, the policy prescriptions derived from static analysis may not remain the same. There is unfortunately much less agreement within the economics profession about the policy prescriptions appropriate for economic growth than for optimum allocative efficiency, so the issue is debatable. It is certainly quite possible that there are large overlaps in the policy measures that would improve both static and dynamic efficiency. Economists have pointed to the effects that measures to improve resource allocation may also have on economic growth — the spur of greater competition, for instance, or exploitation of economies of scale, or the knowledge spillovers that come from links with international markets. It seems quite plausible in reality that there may be substantial fusion of the trade measures affecting both static and dynamic efficiency when trade relations 
are being considered among economies that are at similar levels of technological advancement, have well functioning markets and comparable, supporting market institutions.

But for most developing countries (perhaps leaving aside small countries), whatever the positive effects of foreign trade and investment on economic growth, it seems unexceptional to assert that the pace of such growth depends primarily on the performance of domestic producers. There has to be a body of (private or public) entrepreneurs able and willing to organize new productive enterprises in response to sufficient incentives and supported by a stable framework of legal, financial and technical institutions. But domestic policies, including trade policies, that take account of the need to promote a growing cadre of domestic entrepreneurs, to encourage diversification and to realize the externalities that generate increasing returns, are likely to diverge from those that focus on the improvement of allocative efficiency. The former may argue for discrimination in favor of domestic producers whereas the latter is neutral on the issue.

Thus, even accepting the utilitarian foundation of the criterion of efficiency, it does not provide an unassailably reliable and clear-cut guide to policy. Market failures have to be allowed for, and a dynamic definition does not lead to the same policy prescriptions. But as a surrogate criterion for fairness in the global trading system, its utilitarian basis constitutes a more fundamental flaw. In his critique of utilitarianism, Rawls (1971) noted that the idea of "the greatest good for the greatest number" is not compatible with forms of social cooperation entered into by equals for mutual advantage. All participants expect some benefit and none seek the greatest good of the greatest number. Without reciprocity, the voluntary cooperation does not take place. ${ }^{5}$

Despite the uncertain intellectual basis for the conventional criterion of efficiency, its prescription in support of free trade has a strong visceral attraction for a great many economists. We suggest that the reason lies not solely in the logic of the equilibrium analysis from which it is deduced but in a broader belief based on two observations, one empirical and one historical. First, it embodies the simple, but

\footnotetext{
${ }^{5}$ Amartya Sen (1988) has offered an extensive critique of the efficiency criterion. See, for example, his lectures "On Ethics and Economics.”
} 
irrefutable, truth — so persuasively enunciated by Adam Smith — that specialization raises living standards, and since "the division of labor is limited by the extent of the market," barriers to trade are inherently suspect. Second, it is consistent with the historical observation that capitalist enterprise, operating in ever expanding markets, has appeared to be the most effective way of raising the income and wealth of nations. For many, the outcome appears sufficient justification for the criterion.

\section{Equality of Opportunity and Market Access}

For the developed countries at least, the principles embodied in the GATT/WTO — reciprocity, MFN treatment, and national treatment — appear to have provided a working guide to fairness. The principles have been forged from long historical experience and have proved their value in promoting trade relations. They therefore deserve great respect. However, none of the principles is free from ambiguities or easy to define in operational terms. Perhaps the principle of MFN treatment is the least ambiguous though its clarity is now under heavy attack as the number of bilateral trade agreements, all presented ostensibly as free trade arrangements, has multiplied. ${ }^{6}$ National treatment is fraught with disagreements about its interpretation and application, as we discuss later in the section on equality of opportunity and supporting rules. What we focus on here is the use of reciprocity as a guide to fairness.

\subsection{Reciprocity}

The notion of reciprocity appears operationally important because it assuages the nationalist sentiment that all states harbor and that could otherwise prevent them from gaining the improved market access that they want for their exports. Evidently, no government, unless convinced of the benefits of unilateral trade liberalization, is willing to be accused of giving away more to other states than it receives. ${ }^{7}$ Indeed, it has sometimes been politically important for trade negotiators to claim at home that the concessions received in multilateral trade negotiations are greater than the concessions granted. Were this in some objective

\footnotetext{
${ }^{6}$ We do not comment further here on the relation between these bilateral arrangements and the fairness of the global trading system though the erosion of MFN treatment clearly does harm to the perception of fairness.

7 There may, however, be other motives for participation in a global trade agreement. Some governments, for instance, may welcome participation because it allows them to overcome internal opposition to the opening up of domestic markets. This might make them less insistent on full reciprocity.
} 
sense a reality, trade negotiations might have taken place much more infrequently since they would have amounted to a zero-sum game. But, within the clerisy constituted by the trade negotiators from different nations, this large political obstacle has been surmounted by adoption of equivalence as a conventional basis for mutual concessions.

The convention of reciprocity has undoubtedly played a large role in the history of trade relations. In bilateral trade negotiations, negotiators have often directly compared, product by product, the size of the tariff cuts and the volume of trade involved in order to assure themselves of equivalence. But this certainly is not an exact and faithful characterization of multilateral trade negotiations witnessed in the more recent past. Finger, Reincke and Castro (2002) demonstrated this very clearly for the Uruguay Round. In the tariff negotiations, they found no evidence that countries had sought to negotiate equivalent gains in market access if equivalence is understood in any precise, quantitative sense. Comparing changes in ad valorem tariffs (using $\mathrm{dT} /(1+\mathrm{T})$ as a meaningful measure), they found for their sample that the tariff reductions given and received by individual countries did not correspond. For example, India and South Korea gave their trading partners reductions that amounted to 6.16 percent and 5.99 percent while the reductions they received were 1.22 percent and 1.87 percent. Moreover, when the tariff cuts for the sample of countries were multiplied by the value of the imports or exports to which the cuts applied — a measure of the gains in market access — numerous countries recorded large imbalances. This lack of equivalence might, of course, have been lessened or made greater if we could include the potential gains in market access resulting from the liberalization of trade in services, and from the revisions or introduction of several rules that affected market access.

Nonetheless, it can reasonably be argued that, in recent negotiations among the developed countries, a rough sense of equivalence could be perceived to have guided them even if there was no close accounting of the gains in market access. In each of the major areas of negotiation, the mutual concessions among these countries were roughly comparable. In tariffs, for example, though the average reduction was not exactly the same, the differences were not large (since tariff levels were already low). Likewise, in the service industries, what negotiators sought was national treatment in each other's 
markets, and it could well be argued that, since firms in all these countries were more or less equally able to make gains in the others' markets, the potential gains in market access were comparable. Much the same could also be said of the changes made in rules such as technical barriers to trade, which affect market access.

However, this kind of judgment cannot be so readily made in regard to the outcome of the Uruguay Round negotiations affecting trade relations between the developed and developing countries. There was neither the same symmetry in the different trade measures on which the trade partners made concessions, nor could it be assumed that the supply responses to the reductions in similar measures would be roughly comparable. The most dramatic gain for the developing countries was purportedly the agreement gradually to dismantle the Multi-Fiber Arrangement (MFA). In return, these countries undertook to lower or bind their tariffs, remove quotas, open up their service industries to some degree, and abide by new or revised rules for such matters as subsidies, foreign direct investment (FDI), and intellectual property. In some of these areas of negotiation, such as the service industries or the new or revised trade rules, the gains in market access clearly favored the developed countries. Were these offset by a possible excess of gains accruing to the developing countries that arose from the mutual reduction or removal of tariffs and quotas by all countries? It is evidently extremely difficult to form a judgment and all the more difficult if we add in both the financial transfers implied by the agreement on intellectual property rights — though not a market-access issue at all — and the back-loading of the removal of the MFA quotas. Thus, with regard to the relations between developed and developing countries as reflected in the Uruguay Round outcomes, the criterion of equivalence in market access gains seems to recede into a fog of uncertainty.

Does this mean then that the criterion is useless? This does not appear to be so. In the earlier stages of multilateral trade negotiations, at least in relations among themselves, the developed countries have in the past adopted common formulae for tariff reductions and agreed on the inclusion or exclusion of other negotiable items on the basis of expected reciprocal benefits. It is when negotiations advanced to more concrete and specific levels that the attention of negotiators appears to have shifted from the issue of 
inter-country equivalence to an internal accounting of the political value or cost of the concessions gained and granted. At that point, there is no particular reason to expect any correspondence between the intercountry equivalence implied in the initial framework for negotiations and the political balance sheet drawn up at home. Even so, Finger, Reincke and Castro (2002) found that in the final stages of negotiations on tariff reductions, delegations still sought to assure themselves that all parties had made their “appropriate contributions.”

Again, however, the initial usefulness of the criterion appears to have worked out much less satisfactorily in the Uruguay Round when relations between developed and developing countries are considered. The large differences among these groups of countries in industrial structures and in inherited trade policies (not to mention disparities in bargaining power) made for substantial differences in the content of the bargains struck. So, compared with the bargain struck among developed industrial countries, there was evidently less comparability in the negotiated changes in measures and more uncertainty about the outcomes measured in terms of the consequent expansion in exports.

Still, understood as rough equivalence, the criterion remains important. It counters the nationalist sentiment that can breed mutual mistrust and impede trade cooperation. For such cooperation, it is important that states perceive themselves as being treated as equal, and independent, entities. In so far as the gains in market access can be measured, there is an objective means of assuring every state that it has been so treated. But it has to be admitted that there is great difficulty in translating the criterion into measurable trade outcomes. It is only expected equality of opportunity, not equality of outcome that can be the basis of negotiations among market economies. And if the outcome does not correspond at all to expectations, the sense of fairness is not fulfilled.

\subsection{Initial conditions}

Even if equivalent gains in market access could be realized in the rounds of multilateral trade negotiations, that would not assure countries of equality of opportunity in regard to market access. Countries enter into negotiations with many differences in the level and profile of their trade barriers, and 
equivalent reductions in trade barriers do not eliminate these differences. However, successive rounds of negotiations narrow the absolute differences and may eventually render them unimportant. This has been happening among the developed countries since WWII in non-agricultural goods and has begun more recently in some services.

But between the developed and developing countries, large differences persist. As has long been pointed out, there are biases in the trade barriers of developed countries against the exports of developing countries. The most obvious instance is the array of measures that restrict trade in agricultural products. Certain labor-intensive manufactures, most notably textiles and apparel, face relatively high tariffs. Tariff escalation by the degree of processing of primary products likewise appears directed against products in which developing countries have a comparative advantage. That these kinds of barriers introduce an overall bias into the developed countries' MFN trade policies appears to be borne out by the measure of trade restrictiveness constructed by the IMF and World Bank. (IMF and World Bank, 2004). The measure covers some of the more important trade barriers - MFN tariffs, core non-tariff barriers (NTBs), domestic agricultural subsidy schemes, and the major preferential programs. As Hoekman (2004, p. 14) notes, when the preferential programs of developed countries are left out of the calculations, the measure indicates that low-income developing countries (as defined by the World Bank) would face greater barriers to their exports to OECD countries than would other exporters from developed countries. ${ }^{8}$

On the other side of the coin, it is also a fact that, among developing countries, trade barriers on non-agricultural goods and services remain high across-the-board. Over the last twenty years or so, numerous countries have unilaterally lowered their tariffs on manufactures, lessening the disparity in existing trade barriers. Some countries bound all their tariffs during the Uruguay Round but many bound only some. Whether the coverage was complete or not, the great majority set their bound rates at levels that were substantially higher than their current, applied rates. So many countries have accepted only limited formal obligations in granting market access.

\footnotetext{
${ }^{8}$ It should also be remembered that many of the OECD countries trade on a duty free basis with each other as members of the EU or NAFTA.
} 
The gradual lessening of these embedded biases in trade barriers of both developed and developing countries is a condition of realizing fuller equality of opportunity in market access.

\section{Distributive Equity and Market Access}

Does fairness demand that equality of opportunity in market access be modified, in some degree, to satisfy distributive equity? There are at least two grounds for supporting this position.

One derives from a sense of moral obligation to the poor. The great disparity in levels of living among countries and the very large numbers of people living in extreme poverty have convinced many that the governments of rich countries have a responsibility to assist the poor countries in alleviating their poverty. The most visible expression of this obligation is the provision of aid. But since foreign trade is widely seen to play a part in economic betterment, it is identified as another means of pursuing the same end.

It can also be argued that equality in market access will not be realized so long as some countries are unable to take advantages of the opportunities created by negotiations. The global trading system presupposes the operation of freely competitive markets in which firms in the participating countries respond to new opportunities. But a number of poor countries do not yet have such well functioning markets and merit favorable treatment to strengthen their capacity to exploit new opportunities. ${ }^{9}$

But what does distributive equity mean in the context of the global trading system? It is familiarly associated with the redistribution of income or wealth, but that clearly does not apply here. Though some Third World advocates argued otherwise in past decades, the trading system today is not seen as a vehicle for resource transfers. It is an arrangement for promoting commercial relations among firms and individuals in different countries that are expected to be mutually advantageous. In our view, distributive equity only acquires meaning in this context if the trading system contributes to accelerating the economic development of the poorer countries. This may be accomplished in one, or both, of two ways.

\footnotetext{
${ }^{9}$ Wealthy countries may, of course, have other motives for assistance to developing countries. They may want to promote development in order to limit uncontrolled immigration across borders, or to combat terrorism, or, more broadly, to exercise political influence. But these do not raise the issue of distributive equity.
} 
It is through gains in access to foreign markets that the domestic market can be enlarged and that specialization can be enhanced, leading to such possible beneficial consequences for growth as learning, economies of scale, and technological improvements. More controversially, it is also through protection of domestic markets that, at least in the earlier phases of development, domestic firms (whether nationally or foreign owned) can be induced to establish, to expand and eventually to become competitive with their larger, technologically more advanced foreign competitors. But how far individual countries can gain access to other countries’ markets and how far they can gain their consent to protect their own markets, are matters that have to be settled in their relations with other countries. ${ }^{10}$ Thus, the requirement of distributive equity in the global trading system is presumably that the development of poor countries should be favored through the common pursuit of measures that accord their firms preferred status in their foreign or domestic markets or both.

In practice, developed countries have offered favorable access to their markets through their several non-reciprocal preferential programs. ${ }^{11}$ Under the Generalized System of Preferences (GSP), the developed countries have provided developing countries with preferential access to their markets since the 1970s. In addition, both the U.S. and EU operate other, still more favorable, schemes for particular groups of countries, such as the countries of Sub-Saharan Africa under the U.S. African Growth and Opportunity Act (AGOA) or the EU's Cotonou Agreement that favors the African, Caribbean, and Pacific (ACP) former colonies. Further, the developed countries generally provide still more extensive preferences to the least developed countries. ${ }^{12}$

\footnotetext{
${ }^{10}$ True, we cannot exclude the fact that countries may independently benefit from unilateral reductions in trade barriers and that, indeed, this may be an integral part of their growth strategy. Thus, viewing trade benefits solely in terms of national economic growth does not necessarily provide a comprehensive definition of all the benefits from trade. But it is part of a comprehensive definition and does raise the issue of equity.

${ }^{11}$ These preferential measures are sometimes discussed as though they were a means of redistributing current income generated by trade to developing countries. A criticism of preferential programs is, for instance, that the rent is sometimes captured by importers in the developed countries. But if the intent of the measure is to promote development, what matters is not the effect on the current distribution of trade income but the effect on production and exports in the developing country. Some long-standing preferential arrangements, however, clearly no longer serve any development purpose and are no more than mechanisms for income transfers. The arrangement covering the exports of a few developing countries under the Sugar Protocol of the EU is an example.

${ }^{12}$ For a review of the literature on the benefits of preferences for developing countries, see Hoekman and Ozden (2006).
} 
These preferential schemes have been of some value, though often less than expected. Their product coverage is quite extensive, ranging in 2001 from over 60 percent of dutiable imports into the Quad countries from GSP beneficiaries to 100 percent for imports into the EU from least developed countries under its Everything But Arms scheme once the scheme is fully implemented, according to UNCTAD (2003). Measured as a discount on the MFN rate, the tariff preference also sounds quite large. Mattoo and Subramanian (2004) calculate that, under the GSP scheme of the Quad countries, tariffs are roughly 50 percent below those applied under the MFN, and more under the other schemes. However, in some schemes, the actual use of these preferences falls far short of their potential use. According to UNCTAD (2003, p. 5), under the Quad's GSP schemes, less than 40 percent of the covered imports actually entered the importing countries at the preferential rates. ${ }^{13}$ One possible reason for this lack of use is that exporters found the transaction costs of the certification process too heavy in relation to the saved preferential margin. That is, despite the large discount on the MFN rate, the margin is, in fact, only some 2 to 4 percent on average, according to Mattoo and Subramanian (2004, p. 397). A more common speculation is that exporters were unable to comply with rigorous rules of origin.

The conclusion we draw is that, while the schemes have surely benefited individual producers, their impact on the overall export performance of countries is an open question. The fact that some 60 percent of the products listed under the Quad's GSP schemes were exported without the inducement of a preferential margin suggests that the schemes may have played only a minor role in assisting the export growth of developing countries in general. The main impetus may have come from internal economic growth, structural change, and export-oriented policies.

Much more controversial is the question whether distributive equity demands that the global trading system should also allow developing countries freedom to apply preferential measures in support of firms within their own domestic markets. Responses turn on the causal beliefs held about the effectiveness of protectionist measures in assisting national development. There is ample empirical

\footnotetext{
${ }^{13}$ We should note, however, that the fragmentary evidence, in UNCTAD (2003, p. 6), does seem to indicate that exporting firms in the least developed countries have responded more fully to the inducement, having recorded
} 
evidence that the highly protectionist, import-substituting policies pursued by a number of countries in earlier postwar decades were often detrimental to sustained development. The policies encouraged the emergence of inherently high cost industries, contributed to biases in domestic cost structures that impeded export growth, and sheltered domestic enterprises from competition and the need to innovate. Greater openness has tended to be associated with higher economic growth. However, this criticism of inward-looking policies does not demonstrate that protectionist measures, as part of an array of domestic policies, are ineffective in contributing to the development of emerging countries. The recognition of the value of protection in fostering the establishment of new industries has a long tradition. In providing protection from foreign competition, protection may allow time for new firms to learn and to overcome scale disadvantages.

These differences in causal beliefs are not likely to be resolved any time soon. Practically, the persuasiveness of the one view or the other depends a great deal on the specific circumstances of the individual country under consideration. Countries vary so enormously in their economic size and stage of economic development that any sweeping generalization may justifiably be suspect. This being so, any agreement on how the global trading system can fairly address the issue, is only possible if the differences in causal beliefs are accommodated. This means that the multilateral trade rules should make adequate allowance for the use by countries of protectionist measures that are defensible as developmental policies.

\section{Equality of Opportunity in Supporting Rules}

\subsection{Developed countries}

Reciprocally negotiated reductions in the principal trade barriers are supported by other rules like those relating to customs procedures, the application of sanitary or phytosanitary standards, technical barriers to trade, the use of quantitative restrictions, and subsidies. Some of these rules partly serve to enhance market access in that they facilitate trade and reduce transactions costs. But they also meet the need of trading partners to reassure themselves that the value of the negotiated concessions on direct trade barriers

higher utilization rates. Preferential margins were, of course, higher and perhaps rules of origin were less onerous. 
would not be emasculated by other domestic regulations or practices. Underlying the formation of these rules has again been the criterion of equality of opportunity. Countries have sought equivalent treatment. Along with the procedures for dispute settlement and the use of measures against "unfair" trade, these constitute the rules of the game and are of great instrumental value in promoting a system of cooperation in which trade can flourish.

The process of rule formation has been, and continues to be, a fluid one. Since the GATT was first ratified after World War II, many of the original rules have been repeatedly revisited and revised, and there have been numerous additions to the rules. Most commentators would doubtless agree that countries are now more assured of equitable treatment than was the case fifty years ago; there is less evasion of the formal market-access commitments than there was. But, reflecting the diverse circumstances of member countries, every step forward has been made in the face of often strongly held differences of views on what constitutes a fair rule. Progress has been possible when countries have been able to bridge the gap in their different perceptions of fairness. Their perceptions have not necessarily merged, but they have been sufficiently close to make possible mutual accommodations for the sake of the greater trade cooperation from which they all benefit.

Political obstructionism motivated by a self-interested bias has, of course, not been absent in limiting rule formation. Despite no large differences of perception about fairness, agreement on some seemingly straightforward matters has sometimes been slow to reach. In the 1950s, for example, European countries complained about the so-called American selling price method of customs valuation that the United States used for some chemical products based on the domestic price of an equivalent product. This issue was apparently resolved during the Kennedy Round (1964-1967) in which agreement was reached on the use of customs valuation that would assure equal treatment. But the U.S Congress refused to ratify the agreement, ostensibly on the grounds that the U.S administration had exceeded its 
negotiating mandate. ${ }^{14}$ It was not until the Tokyo Round (1973-1979) that a more uniform method of customs valuation was incorporated in the rules, as Destler (1986, p. 63) has noted.

The difficulty in arriving at rules widely regarded as fair also sometimes stems less from large differences in normative beliefs about fairness than from the technical complexity of the issue. Every national market functions within a framework of norms, laws, institutions and more informal customs that both facilitate and restrict market-driven transactions. While there are certainly some strong, but broad, similarities among the advanced market economies, as, for instance, in commercial laws, the differences in more specific practices are legion. Technical barriers to trade are one such instance, and the agreement reached during the Tokyo Round on these barriers was rightly regarded as a significant accomplishment. While recognizing the right of countries to set their own standards in matters like health, the environment, and consumer safety, the agreement encouraged countries to move toward internationally agreed standards that would facilitate the flow of trade. At the same time, by requiring greater transparency in national inspection and certification procedures, it lessened fears that technical standards would be manipulated to discriminate against traded products. The benefits of the agreement were expected to be reciprocal and therefore accepted as equitable. Its test, however, has lain entirely in whether the specific standards applied by individual countries to particular categories of products are seen as fair by others. (The beef hormone case to be discussed in a later section on procedural justice is one instance of disagreement.)

Agreement about the fairness of proposed rules is always more difficult, and sometimes impossible, to reach when the rules address issues embedded more deeply in national preferences for public goods. It has always been recognized, for instance, that subsidies could nullify or impair the market-access commitments made by countries in trade negotiations, and that some discipline to define the impermissible was needed. But virtually all countries have made, and still make, extensive use of subsidies in support of a wide range of social and economic purposes. These run from income support for

\footnotetext{
${ }^{14}$ It was this experience that led to the introduction in the 1970s of the "fast track" procedure under which the U.S. Congress would have an up or down vote on the entire package of a trade negotiation submitted to it by the
} 
farmers to the rationalization of failing industries to the development of technologically more advanced enterprises. In the commercial sphere, the differences among countries in the use of subsidies are in large part linked to the relation between the state and private enterprise that has evolved over time. The United States, at least over the last 25 years, has emphasized reliance on market-determined decisions, and in the Uruguay Round negotiations, it sought a broad definition of what constituted a subsidy and a narrow definition of subsidies that were not "actionable" under the GATT/WTO. Most of the other developed countries as well as developing countries wanted a more restricted definition of subsidies and a more inclusive set of non-actionable subsidies. Reluctant compromises were made for the sake of reaching some agreement, but it is doubtful if the participants are fully reconciled to all aspects of the agreement, particularly with regard to the possible abuses in using countervailing duties.

The more it is the case that proposed trade rules impinge on different national preferences for social and economic policy, the more difficult it is to agree on their fairness. The preferences may be rooted in strongly held, but different, normative or causal beliefs that make it extremely difficult, or impossible, for countries to agree on what constitutes equality of opportunity. But these preferences cannot be disregarded in rule-making if the system is to be judged fair. They thus set limits on the extent to which trade rules can intrude into national economies.

\subsection{Developing Countries}

As noted, developed countries have been able to arrive at supporting rules when their different conceptions of fairness in the matters addressed have converged sufficiently to make the rules mutually acceptable. The specific terms of their agreements on different issues have, in their eyes, satisfied the condition of equality of opportunity. Until recently, developing countries have been weak and peripheral actors in such rule making, and it cannot be said that their conceptions of fairness have played a comparably influential role. The rules have emerged largely from negotiations among the developed countries, and they have tended to suit their circumstances. Not surprisingly, many developing countries 
have accordingly complained that the rules have been designed with insufficient regard for their particular policy preferences or their distinctively different institutional conditions.

Some proponents of universal application of the rules have argued that most of the obligations placed on developing countries are, in any event, welfare-enhancing since they modernize legal and administrative systems and promote the integration of the countries into the global economy. This judges the rules by the economists' efficiency criterion and, whether the assertion is true or not, it implies an approach that is not consistent with the character of the WTO as a system of rules based on consent given voluntarily.

It is not, of course, practicable that, in a complex, cooperative arrangement like the global trading system, every country should agree to every rule. Consensus has to be reached, and it is right that the world's largest traders should exercise the most influence. But reasonable attention to all differing views and interests is a precondition of voluntary compliance

For many developing countries, a major criticism of some of the rules generated by the Uruguay Round has been that they place constraints on their development policy options. Rules of conduct governing the use of some domestic policy instruments, which are primarily intended to protect marketaccess commitments from nullification or impairment, have appeared to clash with the use of these instruments in pursuit of national development. We have already mentioned the subsidy rules, which will be discussed further below. But a similar concern applies to the agreement on investment (TRIMS), which placed other restrictions on national development policies, particularly in prohibiting import content requirements designed to promote backward linkages as a condition of inward FDI. ${ }^{15}$

\footnotetext{
${ }^{15}$ Investment again figured among the Singapore issues proposed for the Doha Development Round as did government procurement, which may be another instrument of development policy, but these issues were later dropped, following the September 2003 WTO Cancun Ministerial Meeting.
} 
It is evident that many developing countries face a quandary in regard to such issues. On the one hand, from a global viewpoint, it appears entirely reasonable that these countries should subscribe to rules that protect the market-opening commitments they have made in furtherance of their own trade objectives. On the other hand, many do not want to forego the use of such domestic policy instruments for national development. The appropriate line of division between trade and development measures has not yet been satisfactorily drawn in the WTO agreements. ${ }^{16}$

The Agreement on TRIPS, was, of course, a particularly egregious instance of a new condition being introduced into the trading system of rules and procedures without sufficient consultation among countries and without an adequate basis of common consent. Taken by itself, the Agreement lacked for many countries any clear evidence of reciprocal benefit — and, indeed, the benefit by any count was negative for some. Further, until later modified, it rode rough shod over the public goods preferences of many countries for the health of their populations. Proposals to incorporate labor or environmental standards into the WTO rules, with the intent of using trade measures to enforce compliance, have likewise been seen by many developing countries as an intrusion into the conduct of their own social policies. Though often subscribing voluntarily to international conventions on labor or environmental standards, they do not accept that the global trading system should be used as an indirect means of enforcement. Moreover, they fear that the incorporation of such standards would be open to protectionist abuse.

Many developing countries have also complained that there has been insufficient appreciation of the practical problems that they face in implementation of new rules. It has, for instance, often proved burdensome for developing countries to have to comply with technical standards that are established by the developed countries and that require progressively more complex certification and testing procedures.

The WTO has recognized these practical problems in some degree by the provisions attached to

\footnotetext{
${ }^{16}$ In rule formation during the Uruguay Round, the developed countries introduced the idea that, if a policy measure was trade related, it was a legitimate subject for rule formation. That was perhaps consistent with the aim of global market integration but far too all-inclusive. For developing countries, a better rule of thumb would be whether the domestic policy measures cause material injury to a trading partner.
} 
rules that allow for special and differential treatment (SDT). However, the mostly time limited exemptions with usually modestly longer times for least developed countries have appeared unrealistic for many countries.

It has generally been feasible for many countries, especially those long established as nations and with central bureaucracies capable of supporting a functioning market economy, to conform to the common rules, if given sufficient time to draft new domestic laws, revise administrative procedures and train staff. However, for numerous others, mostly small and poor countries without long histories as independent states and with weak central bureaucracies, or extremely small states whose size gives rise to large administrative diseconomies, implementation of some of the rules has confronted them with tasks that are both administratively and financially onerous and often rank low in their list of domestic priorities. Finger and Schuler (2000) have pointed out, for instance, that to conform to the WTO prescribed method of customs valuation, countries must first have in place an effective and modernized customs administration, and that is often not the case. An extensive overhaul of the existing customs administration thus becomes a prerequisite of conforming to the WTO rules.

In our view, realism demands a franker recognition by WTO members that there are a number of countries whose state institutions or economic size do not equip them to undertake fully all the obligations of the multilateral trading system. And it is equally only realistic to acknowledge that the development of the needed range of institutions will often take, not years, but decades. Hoekman, Michalopoulos, and Winters (2004) have proposed that the countries qualifying for exemption should be composed of those that meet certain broad criteria like per capita income, institutional capacity, or economic scale; it would include all the least developed countries together with some other poor countries penalized by small size. These countries are capable of complying with core rules relating to MFN treatment, tariff binding obligations, the eschewal of quantitative restrictions, dispute settlement procedures, and trade-remedy measures. But any demand that they comply with all rules dissociates rulemaking from reality.

An objection to the view just expressed is that it would be politically difficult in the setting of a 
multilateral agency where decisions are made by consensus - to agree on the qualifying countries. The difficulty comes, not in adding countries to the qualifying list, but in excluding or graduating them from the list. Keck and Low (2006) discuss other proposals that refine the criteria and make them rule-specific. This approach does not alter the need for political decisions, but in diffusing the decision-taking among a number of rules, it might lessen the political difficulty. On the other hand, it envisages a more laborious process. In this context, it is also worth noting that it has proved feasible for the UN to establish, and periodically review, its list of least developed countries. ${ }^{17}$ Moreover, what is at stake for other members of the WTO in agreeing to a list of countries that might err on the side of generosity, is very minor. The importance of these countries in world trade is miniscule. In their analysis of the role of these countries in the Doha Round, Mattoo and Subramanian (2004) drew up a list of 62 countries whose combined share in world imports of goods and services was a mere 1.1 percent.

\section{Procedural Justice}

Though broad agreement may be reached on the fairness of the adopted rules, this does not assure agreement on the fairness of their application. Conflicting parties may have quite different interpretations of the rules, being influenced not only by raw self interest but also by their particular normative and causal beliefs. Whichever way contested rules are applied, they are not likely to satisfy all the affected parties. All that can be accomplished is to ensure that the procedures for interpretation and application of the rules are themselves fair. A number of the WTO's rules and agreements are, in fact, designed and implemented with the objective of establishing such procedural justice not only in dispute settlement, but also in such other matters as measures dealing with unfair trade and the negotiating process.

Most would agree that the dispute settlement machinery established as part of the Final Act of the Uruguay Round has generally worked well. A number of developing countries have successfully used the machinery, and it has proved important in resolving disputes among the leading trading nations. The task

\footnotetext{
${ }^{17}$ First established in 1971, the list contained 25 countries, and it now numbers 50 . The reasons for the increase appear to have been several; these include the broadening and refinement of the criteria, improvements in data, the
} 
of adjudication is, however, a delicate and difficult one, for the adjudicators have to be careful not to go beyond the consensus views on what constitutes fairness. For example, in the EU-U.S. dispute over the EU ban on imports of genetically modified (GM) foods, the semi-judicial process was called upon to define the line between commercial activity and collective preferences. In order to accommodate differences among countries in their collective preferences for health and safety standards, the WTO rules allow countries to ban imports that do not conform to the standards that they have set for themselves. However, because of the fear that countries could abuse these rules for protectionist purposes, it was also agreed during the Uruguay Round that any restrictions imposed on health grounds should be scientifically defensible. In the case of the GM foods, the EU argued in support of its imposition of a ban on imports that there was insufficient scientific evidence that the foods did not harm human health. The U.S. response was that there was no evidence of harm to human health. Thus their disagreement was not on the scientific evidence but on a difference in assessment of risk. This is a normative difference that precludes the emergence of a shared view on what is fair, although assessments of risk may change over time as new scientific evidence becomes available. ${ }^{18}$

Provided the dispute-settlement bodies stay within the spirit of the agreed rules, the fairness of the dispute-settlement machinery then turns on whether its procedures are equitable. One apparent inequity that many have pointed out is the asymmetry between large and small countries in their capacity to penalize any failure to comply with a judgment. If a small country is authorized by the Dispute Settlement Body to raise tariffs on goods from a much larger trading partner, this does not have the same effect as in the reverse case. The experience is, however, that the larger countries have not been encouraged to ignore dispute settlement rulings. They have evidently been willing to conform to rules of conduct that they have agreed to as fair in past negotiations. ${ }^{19}$ A practically more important inequity,

absence of sustained economic growth, or the actual worsening of economic circumstances in some countries. Failure to graduate countries appears to have played only a minor role in enlarging the list. (UN, 2003)

${ }^{18}$ The turtle/shrimp dispute raised still subtler issues of the boundary between commercial activities and collective preferences.

${ }^{19}$ That is, they are recognizing the value of cooperation when the game is endlessly repetitive. 
discussed by Hoekman and Mavroidis (2000), for many of the smallest and poorest countries is their inability to utilize the dispute-settlement process because of their lack of legal and informational resources.

When we turn to measures to defend against alleged "unfair" trade, the problems are different. It has long been recognized in trade agreements that trading partners should have the freedom to set aside their trade obligations unilaterally under certain circumstances. Thus, the WTO Agreements permit member countries to take action against predatory pricing, the subsidization of imported goods, or import surges. The difficulty is that the freedom is open to abuse - as frequently happens when domestic producers exploit the provisions to obtain protection for their industries. The provisions are especially vulnerable to such abuses since they rely on administrative decisions within the importing countries for their application. While efforts were made during the Uruguay Round to specify more carefully the criteria and procedures that countries were obliged to adhere to in considering defensive action, it remains a fact that the semi-judicial function is carried out by the administrative authorities in the importing countries. Still more exact specification of the criteria and procedures to be applied under the Agreements could further narrow the scope for administrative discretion in their application, but some room for interpretation would inescapably remain. What would do still more to enhance procedural fairness would be the transfer of the semi-judicial function to more independent bodies.

\section{Fairness and the Doha Round}

Having reviewed at some length the different concepts of fairness that in our view are of paramount importance, we now consider how the issues of fairness can be applied in the context of the Doha Round. We begin by discussing the principles of fairness that Stiglitz and Charlton (2004) recommend to be applied in the Doha Round and that have attracted considerable attention. Thereafter, we draw upon the two concepts of fairness - equality of opportunity and distributive equity — with reference to their applicability to the Doha Round negotiations. 


\subsection{Stiglitz and Charlton Principles of Fairness}

Stiglitz and Charlton (2004) have proposed a set of principles of fairness that they argue should provide a framework for the ongoing Doha Development Round negotiations. ${ }^{20}$ They state (p. 11) that: "It seems self-evident that:

1. Any agreement should be assessed in terms of its impact on development; items with a negative effect on development should not be on the agenda.

2. Any agreement should be fair.

3. Any agreement should be fairly arrived at.

4. Any agreement should be limited in scope."

The first principle calls for the use of general equilibrium incidence analysis to be carried out under WTO auspices to determine how countries are affected by different proposals for trade liberalization. The point is to determine which policies maximize the welfare gains for developing countries in particular. The second principle involves a "fairness constraint," such that the outcome of any liberalization agreement provides a larger share of aggregate benefits to the poorer countries, net of domestic efficiency effects due, for example, to reduction or removal of domestic subsidies such as agricultural supports. The third principle of "procedural” fairness refers to the openness, transparency, and conduct of the negotiation process and dispute-settlement resolution. It includes the design of the negotiating agenda and dispute-settlement procedures in ways to attain greater symmetry of power and information among both developed and developing WTO member countries. The fourth principle calls for limiting the scope of issues comprising the negotiating agenda and avoiding unwarranted intrusions into national sovereignty.

In discussing their first principle, Stiglitz and Charlton (2004) and Charlton and Stiglitz (2005) cite the widespread use of computable general equilibrium (CGE) models that are designed to provide

${ }^{20}$ It is noteworthy in this connection that when he was Senior Vice-President and Chief Economist at the World Bank, Stiglitz (2000) favored the principles of "fairness" and "comprehensiveness." However, he did not then spell out what he meant by fairness. He interpreted comprehensiveness to cover a wide variety of issues of potential benefit to developing countries, including what later have become referred to as the "Singapore issues." More 
estimates of the potential welfare effects of alternative negotiating options. While they consider CGE modeling results as suggestive, they note that most of these models are comparative static in construction and typically do not take into account adjustment costs and potential dynamic effects of liberalization on productivity, flows of FDI, and changes in capital formation, all of which may be growth enhancing. Granting these qualifications about the present state of the art in CGE modeling and taking into account the lack of data on the trade barriers and domestic economic structure of most poor countries especially, we consider it unlikely that the Stiglitz-Charlton first principle of using modeling focused on developing country interests can be achieved in the short period of time to be covered by the Doha negotiations.

The Stiglitz-Charlton first and second principles appear to be a combination of the efficiency criterion with an emphasis on the welfare gains to be assessed by modeling efforts together with an application of the principle of distributive equity. The principle of distributive equity presumably enters in by analyzing alternative negotiating options that are focused on enhancing developing country welfare. But this fails to recognize that the criterion of efficiency is defective as a yardstick of fairness in the global trading system. Equality of opportunity, not maximum benefit as defined in general equilibrium analysis, is the condition that would collectively satisfy fairness, modified in some degree by recognition of distributive equity. Gains in static welfare are affected by these arrangements but the optimization of static welfare - or its distribution among countries — cannot be used to determine what a fair set of arrangements should be. ${ }^{21}$ Further, as we have argued, distributive equity in global trading arrangements appears to make more sense if understood as a means of promoting development through the provision of preferential treatment at home or abroad to the firms of poorer countries.

recently, Charlton and Stiglitz (2005) have set forth a narrower scope of the priorities that they recommend for the Doha negotiations, with an emphasis on achieving greater market access for developing country exports.

${ }^{21}$ Srinivasan (2005) provides a critique of the various writings and proposals of Stiglitz and Charlton. As he notes (p. 12): “...it is not obvious why the share of benefits from an agreement that accrues to poorer countries necessarily has to rise for it to be fair." 
The Stiglitz-Charlton third and fourth principles are less problematic, being similar to what we have discussed under the headings of procedural justice and the limitations imposed on equitable supporting rules by the need to respect differences in national social and economic beliefs and practices.

\subsection{Achieving equality of opportunity and distributive equity in the Doha Round}

We have presented our interpretation of fairness under the heading of two criteria: equality of opportunity and distributive equity. At the present time, it cannot be said that the global trading system corresponds closely to these two criteria, and there is ample scope for improvement in the Doha Round. Some of the rules supporting market access, as we have indicated earlier, do not sufficiently accommodate different national conditions, institutions or policy preferences to be generally accepted as fair, even when taken as a package. Procedural justice is also far from having been reached. However, we will confine our remaining comments to the primary issue of fairness in the market-access arrangements prevailing between developed and developing countries. ${ }^{22}$

Equality of opportunity in the negotiation of gains in market access is a definition of reciprocity. We have noted earlier that reciprocity has served well enough in past negotiations among developed countries but that, when applied to negotiations between developed and developing countries in the Uruguay Round, it appeared to be a very vague and uncertain criterion. The reason was that, whereas for the developed countries, the criterion could be applied within each of the sectors or issues on which mutual concessions were negotiated, between developed and developing countries there was much less symmetry in the sectors and issues being negotiated, and large trade-offs were made across them. This is unfortunate since fairness can be more readily assessed when negotiations relate to like sectors or issues. However, so far as market-access negotiations are concerned, some bargaining across sectors is

\footnotetext{
${ }^{22}$ It is an anomaly of the present arrangements that removal of some of the existing distortions could seriously penalize some small countries. The reduction of subsidies and trade barriers to agricultural products is likely to have adverse effects on a number of countries that now enjoy preferred access to developed country markets or benefit from subsidized food imports. For some small countries, heavily dependent on a single export crop, the consequences may be particularly severe. The most elementary notion of fairness dictates some form of compensation.
} 
inescapable — though there could possibly be merit in striving for reciprocity within sectors. ${ }^{23}$ Still, there would be some gain in clarity if the fairness of market-access negotiations were assessed separately from those relating to rule-making and procedural justice. As we have already argued, other standards of fairness apply to the latter.

A move to adhere more closely to market-access gains, of course, does not address the biases inherent in preexisting trade barriers or the great disparity in national economic conditions that give rise to the call for distributive equity. There is, as we have noted, a recognized bias in the trade barriers of developed countries against many of the products in which the developing countries have a comparative advantage. Developed countries can claim that the bias is offset by their non-reciprocal preferential programs and by the less-than-full reciprocity that they concede to developing countries in tariff negotiations. We suggest, however, that both fairness and efficiency would be better served if, over time, the bias in trade barriers were progressively removed while developing countries, apart from the lowincome and least developed countries, moved closer toward full reciprocity.

An alternative to removal of the bias in developed countries' trade barriers is to make their nonreciprocal preferential programs larger and more effective. But it is highly improbable that these programs are ever likely to be made a more extensive instrument of promoting development in most developing countries. The successful export performance of a number of these countries alone militates against their more extensive use. Moreover, if the rationale of these programs is to encourage the formation and expansion of export-oriented firms and not to transfer income to developing countries, then the programs seem largely relevant for low income and least developed countries in the early stages of diversifying their production and exports. These programs have, in addition, undesirable characteristics when measured by the efficiency criteria. They generate inefficiencies in diverting trade from the lowest cost producers, and they create overlapping rules of origin. Further, they are not necessarily stable, since they are extended unilaterally and can be arbitrarily withdrawn. In comparison with multilateralism,

\footnotetext{
${ }^{23} \mathrm{An}$ obvious example in services is the right to make temporary transfers of low cost labor in order to fulfill construction contracts.
} 
weaker countries are less protected from the use (or abuse) of trade measures by the powerful for nontrade aims.

We can also ask whether less-than-full reciprocity in tariff negotiations best serves the criterion of distributive equity if that is taken to mean favorable treatment of developing countries in order to promote their development. Developing countries appear to have been deterred from full reciprocity in part because of their belief that they should be able to protect their domestic production more than developed countries both for infant-industry reasons and because of the limitations on their capacity to adjust. There are good arguments, however, in moving toward full reciprocity, not least of which is that larger tariff cuts would encourage trade with other developing countries. But concerns about infant industries and sensitive lines of production also need to be taken into account if some weight is to be given to distributive equity. This might be accomplished by more specific measures than less-than-full reciprocity in across-the-board tariff cuts. For example, exclusion of a proportion of tariff lines from the tariffcutting formula as proposed by India at one stage, makes more specific provision for branches of production that countries may continue to want to protect. On agriculture, a similar proposal has been made that certain "special products," mostly crops of subsistence of semi-subsistence smallholders, should be excluded from liberalization measures. ${ }^{24}$

Another, still more specific measure would be revision of the rules governing the ability of countries to alter their tariff commitments on infant-industry grounds. GATT/WTO rules have long allowed countries to break their bound tariff commitments on these grounds, but the relevant part of Article (XVIII A) has been largely unused. This was mostly because, when the need arose, it was possible to invoke balance-of-payments reasons for breaching commitments, though the obligation to compensate affected trading partners for the losses sustained from raising tariffs has surely been an added deterrent. With conditions for use on balance-of-payments grounds made more rigorous, the issue of compensation

\footnotetext{
${ }^{24}$ The protection of agriculture is, as we have suggested, something of a special case. The costs of adjustment to agricultural liberalization can be heavy in many developing countries, even threatening social cohesion. Particularly when staple crops are affected, there may be grounds for protection that are not developmental in the familiarly understood sense.
} 
comes to the fore. It is a highly restrictive condition, and it is accordingly difficult to say that the rule provides significant freedom to developing countries in the use of tariffs as a development measure. One possible solution would be waiver of the commitment under specified circumstances, possibly providing for a permissible number of waivers over a ten-year period. This is not far removed from the provisions in the present Agreement on Safeguards in which the protection of injured industries may be instituted in developing countries for a period of up to ten years.

The rules on subsidies and countervailing measures would similarly require revision. The present Agreement recognizes, in general terms, that domestic subsidies may play an important role in the economic development programs of developing countries. This, however, is not explicitly allowed for in the operational provisions of the Agreement. Domestic subsidies that may be challenged by trading partners include any that nullify or impair the benefits they are accorded through the binding of tariffs; and this again gives developing countries an incentive not to bind their tariffs or not to lower them. A provisional clause in the Agreement defined "actionable subsidies” to include subsidies such as those for regional development within countries or to support the implementation of environmental regulations, but it contained no reference to developmental subsidies. The clause was allowed to lapse in 2000, and its replacement would be the opportunity for a more development-oriented definition.

\section{Conclusion}

Any attempt to define fairness in global trade relations should teach a certain humility. Even if we could transcend the self-serving bias inherent in the judgment of all interested parties, there is still no conclusive and incontrovertible way of assessing fairness. We have suggested a framework composed of two criteria: equality of opportunity and distributive equity. Equality of opportunity is realized when there is reciprocity among countries in the reduction of trade barriers, when they adhere to MFN treatment, when the biases in initial conditions are removed, when the rules supporting market access are not only seen as equivalent but are also consistent with national preferences within countries, and when procedural justice is respected in such matters as dispute settlement and the use of trade-remedy measures. Equality of 
opportunity, however, has to be modified in some degree to allow for distributive equity — understood as the promotion of development. In this framework, the criterion of efficiency is not a primary yardstick of fairness, but it is relevant in choosing among ways in which fairness can be realized.

We have noted that, in market-access negotiations, reciprocity is of most value in realizing fairness, when negotiations are confined to like sectors or sub-sectors; it becomes more difficult to assess fairness when negotiations are more comprehensive. But in assessing fairness, a clear distinction should at least be drawn between market-access negotiations — to which reciprocity applies — and other rulemaking issues — for which other standards of fairness are relevant. We have also noted that the substance of supporting rules and the introduction of new rules face limits posed by the diversity that exists among countries in their aims and conditions. Rules will only be regarded as fair if they respect the different, but strongly-held, national preferences.

We have argued that, in the context of the global trading system, distributive equity has meaning only in one particular sense. It has to be understood that the global trading system is not a vehicle for income transfers but an arrangement for furthering mutually advantageous commercial relations among countries. Since trade can help promote the development of the poorer countries, the relevant consideration is the effect of the system in doing so. Distributive equity thus turns around the question of whether the trading system gives preference to the efficient growth of production in the poorer nations through sales in foreign or domestic markets.

At present, the bias in the trade barriers of developed countries against goods and services in which developing countries may have a comparative advantage is only modestly offset by the nonreciprocal preferential arrangements that are in force. However, apart from those that apply to the least developed and other mostly small and poor countries, these preferential arrangements are not likely to be improved. Developing countries generally would, in any case, probably benefit more from a progressive reduction in the bias in developed countries' trade barriers. If this were accompanied by the embrace of fuller reciprocity in tariff reductions on their part, they would move into a more equal partnership with the developed countries in the global trading system. With the rise of the large, industrially more advanced 
countries like Brazil, China, India and South Africa as significant trading partners, that would seem the likely course of future events anyway. But many developing countries still have great poverty and are not going to shed their developmental status for many years. As we see it, the WTO rules should fully recognize this status by assuring them the option to use specific developmental measures. 


\section{References}

Carraro, Carlo, Carmen Marchiori, and Alessandra Sgobbi. 2005. “Advances in Negotiation Theory: Bargaining, Coalitions and Fairness,” Fondazione Eni Enrico Mattei, Nota di Lavoro 66, 2005 (May).

Charlton, Andrew H. and Joseph E. Stiglitz. 2005. "A Development-friendly Prioritization of Doha Round Proposals,” The World Economy 28:293-312.

Destler, I.M. 1986. American Trade Politics: System Under Stress. Institute for International Economics, and The Twentieth Century Fund. Washington D.C.

Finger, Michael J. and Philip Schuler. 2000. "Implementation of Uruguay Round Commitments: The Development Challenge,” The World Economy 23: 511-524.

Finger, Michael J, Ulrich Reincke and Adriana Castro. 2002. "Market Access Bargaining in the Uruguay Round: Rigid or Relaxed Reciprocity?” in Jagdish Bhagwati (ed.), On Going Alone: The Case for Relaxed Reciprocity in Freeing Trade. Cambridge: MIT Press.

Hoekman, Bernard. 2004. "Dismantling Discrimination against Developing Countries: Access, Rules and Differential Treatment,” Discussion Paper Series No 4694. Centre for Economic Policy Research, London.

Hoekman, Bernard and Caglar Ozden. 2006. "Trade Preferences and Differential Treatment of Developing Countries: A Selective Survey,” in Bernard Hoekman and Caglar Ozden (eds), Trade Preferences and the Trading System. Cheltenham: Edward Elgar Publishers.

Hoekman, Bernard, Constantine Michalopoulos and L. Alan Winters. 2004. "Special and Differential Treatment of Developing Countries in the WTO: Moving Forward After Cancun,” The World Economy 27:481-506.

Hoekman, Bernard and Petros C. Mavroidis. 2000. "WTO Dispute Settlement, Transparency and Surveillance,” The World Economy 23:527-542.

International Monetary Fund and World Bank. 2004. Global Monitoring Report. Washington, D.C.

Kapstein, Ethan B. 2006. Economic Justice in an Unfair World: Toward a Level Playing Field. Princeton: Princeton University Press.

Keck, Alexander and Patrick Low. 2006. "Special and Differential Treatment in the WTO: Why, When and How?" in Simon J. Evenett and Bernard M. Hoekman (eds.), Economic Development and Multilateral Trade Cooperation: London and Washington, DC: Palgrave/McMillan and World Bank.

Mattoo, Aaditya and Arvind Subramanian. 2004. "The WTO and the poorest countries: the stark reality, World Trade Review 3:385-407.

Narlikar, Amrita. 2005. "Fairness in International Trade Negotiations: Developing Countries in the GATT and WTO," Conference on "Political Economy of Fairness and Globalization," Tulane University (April). 
Rawls, John. 1971. The Theory of Justice. Cambridge. MA: Harvard University Press.

Risse, Mathias. 2005. "Fairness in Trade," Conference on "Political Economy of Fairness and Globalization,” Tulane University (April).

Sen, Amartya. 1988. On Ethics and Economics. London and Cambridge, MA: Blackwell.

Srinivasan, T.N. 2005. “Doha Round of Multilateral Negotiations and Development,” in process.

Stiglitz, Joseph E. 2000. “Two Principles for the Next Round or, How to Bring Developing Countries in from the Cold,” The World Economy 23:437-54.

Stiglitz, Joseph E. and Andrew Charlton. 2004. “The Doha Round of Trade Negotiations: An Agenda to Promote Development and Facilitate Adjustment,” Commonwealth Finance Ministers Meeting, Provisional Agenda Item 7, FMM(04)15, St Kitts \& Nevis, 28-29 September.

Suranovic, Steven M. 2000. “A Positive Analysis of Fairness with Applications to International Trade,” The World Economy 23:283-308.

Thucydides. 1934. The Peloponnesian Wars. The Modern Library, New York.

Wonnacott, Paul and Ronald Wonnacott. 2005. "What's the Point of Reciprocal Trade Negotiations? Exports, Import and Gains from Trade,” The World Economy. 28:1-20

UNCTAD. 2003. Trade Preferences for LDC's: An Early Assessment of Benefits and Possible Improvements. UNCTAD/ITCD/TSB/2003/8, Geneva.

United Nations (UN). 2003. “Local development and global issues,” Report of the Committee for Development Policy on the fifth session, 7-11 April. NewYork: United Nations. 